\title{
Environmental Risk of Atrazine (Herbicide) to Brain, Gills and Liver Tissues of Fish Ctenopharyngodon idella (Valenciennes, 1844)
}

\author{
Waqar Ahmad1, Aamir Sultan1, Sahibzada Muhammad Haseeb Jan1, Aamir Ali', \\ Ihtisham Ur Rahman', Hazrat Usman', Ahmad Sher', \\ Naqash Khan1, Suleman1, Zahid Khan1, Ahsan Khan1,2* \\ ${ }^{1}$ Department of Zoology, University of Swabi, Anbar, Swabi, Khyber Pakhtunkhwa, Pakistan \\ ${ }^{2}$ Department of Zoology, University of Peshawar, Khyber Pakhtunkhwa, Pakistan \\ Email: *Ahsanyousafzai27@yahoo.com
}

How to cite this paper: Ahmad, W., Sultan, A., Jan, S. M. H., Ali, A., Rahman, I. U., Usman, H., Sher, A., Khan, N., Suleman, Khan, Z., \& Khan, A. (2021). Environmental Risk of Atrazine (Herbicide) to Brain, Gills and Liver Tissues of Fish Ctenopharyngodon idell (Valenciennes, 1844). Journal of Geoscience and Environment Protection, 9, 1-16.

https://doi.org/10.4236/gep.2021.92001

Received: November 13, 2020

Accepted: February 1, 2021

Published: February 4, 2021

Copyright $\odot 2021$ by author(s) and Scientific Research Publishing Inc. This work is licensed under the Creative Commons Attribution International License (CC BY 4.0).

http://creativecommons.org/licenses/by/4.0/

\section{(c) (i) Open Access}

\begin{abstract}
The current study investigates the toxic effects of acute dose of an endocrine disruptor atrazine on Grass carp (Ctenepharyngodon idella) using histopathological changes as biomarkers. Histopathology is promising field for research in aquatic toxicology, in this manner vital organs; brain, gills, and liver tissues were inspected histological after exposing to sublethal groupings of atrazine 0.025 and $0.03 \mu \mathrm{l} / \mathrm{L}$ for 3, 6, 9, 12 and 15 days individually with equal untreated control group. Against various doses, rapid movements, gulping of air and jumping of fish to scat from toxic medium were noticed. Various severe $(+++)$ morphological modifications in tissue were documented in comparison with control group comprised of degenerated neurons, vacuolization, inflammatory cells infiltration and neural necrosis in brain tissue. The most well-known gills tissue alteration at all concentrations of atrazine was epithelial hyperplasia, desquamation, epithelial lifting and smaller aneurism while hepatic injuries were described by overcast expanding of hepatocytes esteemed as cloudy swelling of hepatocytes followed by karyolysis, karyohexis and dilation of sinusoids which shows that atrazine introduction upgraded the toxicosis impacts with the increase concentration, influenced the strength of the fish, inferable from histological inconsistencies.
\end{abstract}

\section{Keywords}

Histopathological, Toxicological, Brain, Gills, Liver 


\section{Introduction}

Various classes of pesticides are presently often utilized against various pests, to build the creation of crops despite the fact that these are profoundly poisonous to other non-target species in the earth (Pandey et al., 2008; Naqvi et al., 2016). Deposits of pesticides arrive at the aquatic environment, representing threat for the non-target creatures compromising the ecological balance and biodiversity (Asita \& Makhalemele, 2008). Accordingly non-target life forms are presented to a blend of pesticides which may incite histological harm indicating serious issue at nearby, territorial, national and worldwide scale (Cerejeira et al., 2003; Könen \& Çavaş, 2008). Herbicides picked up consideration due to their harmfulness, aggregation and unsafe consequences for aquatic environments, fish and the human wellbeing (Javed, 2012; Matsumoto et al., 2006; Theodorakis et al., 1998).

Scrutinizing of xenobiotics in freshwater biological system by mean of occupant species can assist in assessment of quality of aquatic ecosystem. Some these harmful substance remains in the surroundings especially aquatic bodies for long time and may influence physiology of fish by creating tissue anomalies at histological levels (Roy et al., 2006; Vinodhini \& Narayana, 2009; Velmurugan et al., 2009). Fishes are being utilized as valuable model for the assessment of contamination in sea-going condition (Nagarani et al., 2012). Fish have been regularly utilized as fitting bioindicators of chemicals contaminants (Sinaie et al., 2010; Tolosa et al., 2005; Zuloaga et al., 2009). For determining the health status of fish, histological biomarkers are considerd as the effective tools and thus mirror the soundness of the whole water biological system (Nikalje et al., 2012).

Pakistan are among the nations confronting intense freshwater contamination issues where just $1 \%$ of industrial and agricultural water is treated before its release into the aquatic bodies (Khan et al., 2012). In this way, overwhelming releases of untreated water into the streams of Pakistan are antagonistically influencing the new water fisheries (Jabeen \& Javed, 2012) and the indigenous fish species are nearly augmentation in the rivers of Pakistan (Rauf et al., 2009).

Herbicide adds needful increment in crop yields but on the other hand the polluting of aquatic bodies through splash float and draining from the soil of these chemicals may induce unwanted biological and dangerous health impacts on a variety of non-target life forms including fish that lead to fish mortality, decreased fish profitability or raised concentration of unwanted synthetic chemicals in edible fish tissue can influence the health of human (Adedeji et al., 2009).

Atrazine (ATR) has been one of the most generally utilized herbicides to control wide leaf weeds in corn or yields, including green vegetables (Cui et al., 2002). In the wake of splashing on crops, it can enter aquatic bodies, due to its high mobility through soil (Waring \& Moore, 2004). Hussein et al. (1996) no- 
ticed that ATR travels end in aquatic bodies because of vicinities of the agricultural countrysides to water or straightforwardly because of the thoughtless application in such environment. Subsequent to arriving to the surrounding environment at the atrazine or triazine based herbicides are not degraded by microbial or hydrolytic process, however, WHO (1996) reports find out that atrazine can be debased in surface water by photolysis and microorganisms and the half life of 20 - 50 days at $20^{\circ} \mathrm{C}-25^{\circ} \mathrm{C}$ have been found under research facility conditions and increasing at lower temperatures (USEPA, 1988). It has been identified in natural and surface waters at concentration exceeding $0.1 \mathrm{gl}^{-1}$ in certain regions and furthermore aggregated in various tissues of aquatic fauna (Du Preez \& van Vuren, 1992). Different authors have revealed the effect of atrazine on the physiology and metabolism of aquatic living beings especially on fishes (Prasad et al., 1991; Hussein et al., 1996; Grobler et al., 1989; Srinivas et al., 1991; Prasad et al., 1995; Phyua et al., 2006). Therefore, the main purpose of the present study was to investigate the tissue damage in the freshwater fish, $C$. idella after in vivo acute exposure to various doses of atrazine.

\section{Materials and Methods}

\subsection{Chemical and Study Duration}

Herbicide selected for this study is atrazine that is extensively used in agricultures, residential and commercials settings. The proposed study was designed to assess the toxicological impact of atrazine (99.5\% purity, Chem-service, USA) at two dose levels i.e. 0.025 and $0.03 \mu \mathrm{L} / \mathrm{L}$ for a duration of 3, 6, 9, 12 and 15 days respectively in grass carp (C. idella).

\subsection{Test Animal}

Healthy and uniform size seeds of grass carp, normal body weight $3.23 \pm 0.34 \mathrm{~g}$ were bought and moved in oxygenated packs from Peshawar and Mardan carp incubation center to Fisheries and Aquaculture research lab, Department of Zoology, University of Swabi. Water was filtered with an open streaming filter, comprising of filter wadding, activated charcoal, and magma stones. Fish were stored inside two aquariums, each with a volume of $500 \mathrm{~L}$, before the start of the experimentation. They were adjusted semi-static to circulated air through and standard OECD water at temperature of $25^{\circ} \mathrm{C} \pm 1{ }^{\circ} \mathrm{C}$ under typical photoperiod of $11-13 \mathrm{~h}$ for 3 weeks. The hardness and $\mathrm{pH}$ of water were $250 \mathrm{mg} \mathrm{CaCO} \mathrm{L}^{-1}$ and $7.4 \pm 0.01$, individually. The medium utilized was filtered and the degrees of $\mathrm{NH}_{4}, \mathrm{NO}_{2}$ and $\mathrm{NO}_{3}$ in the water recorded to be inside $0.1,0.1$ and $20 \mathrm{mg} \cdot \mathrm{L}^{-1}$, separately. During acclimatization, fish were taken care of once every day with artificial food (Biomar Co., Iran) at a pace of $1 \%$ of biomass. Fish were randomly assigned to $100 \mathrm{~L}$ fiberglass tanks (3 imitate tanks for each treatment). The tanks were persistently circulated air through and $10 \%$ of the water was changed day by day and the chlorpyrifos dosing was restored in like manner. 


\subsection{Sample Collection}

After stipulated time three fish from every aquarium in the control and treated group were captured with a hand net and sacrificed. Brain, gills and liver tissues were removed by decapitation and placed in sera (absolute alcohol, formaldehyde and glacial acetic acid in 6:3:1 ratio) for the further histology process and all samples were stored at $-20^{\circ} \mathrm{C}$ before analysis.

\subsection{Histopathological Parameter}

Bell et al. (2000) method was adopted for the preservation of tissues and preparation of slides for histopathological assessment. Tissues were preserved in 10\% formalin for histologic studies. The preserved tissues were processed in various grades of ethanol, cleared in xylene and impregnated with wax $\left(\mathrm{mp} ; 58^{\circ} \mathrm{C}\right)$. Five microns thick sections were cut using rotary microtome (LeicaRM2165) at 100x. Tissues sections were stained with hematoxylin and eosin (H \& E). Stained slides were observed and photographed under high resolution microscope (Lecia, Japan) fitted with a digital camera.

\subsection{Statistical Analysis}

Three types of histopathological effects: none $(-)$, mild $(+)$, moderate $(++)$, and severe $(+++)$ effects in the tissues of grass carp exposed to atrazine were reported (Faheem et al., 2016).

\section{Results}

No mortality was seen during the sublethal concentrations. However, as the time passed, the fish indicated abnormal swimming behavior, flighty swimming and loss of equalization. Atrazine is moderately to exceptionally poisonous to estuarine and freshwater fish. In this examination, fish were exposed to the concentrations of atrazine levels underneath the LC50. The structure of normal brain of the control fish comprises of clear neural cells with particular nuclei is shown in Figure 1. There were no discoloration, no sore and any morphological change in the brain tissue of control fish. On exposure against grouping of 0.25 and 0.03 $\mu \mathrm{l} / \mathrm{L}$ contrasted with the control, severe degenerative changes were seen in the neural cells of the brain of the fish C. idella and with the increase in the dose and duration, incremented in the severity of the anomalies were observed as degenerated neurons and inflammatory cells infiltration as shown in Figures 1(a)-(d) and Figure 1(g). Likewise other alteration against the doses were reported as acute necrosis of neurons, vacuolization of neuropil, irregular pyramidal cells, neurol necrosis and binucleate formation as shown in Figure 1. Severity of anomalies of brain tissues in comparison with control group against atrazine doses is shown in Table 1.

No histopathological changes were seen in the gills tissue of the control fish. The structure details of the gills of control $C$. idella are appeared in Figure 2. Histological perception of the gills tissue after treatment against 0.025 and 0.03 

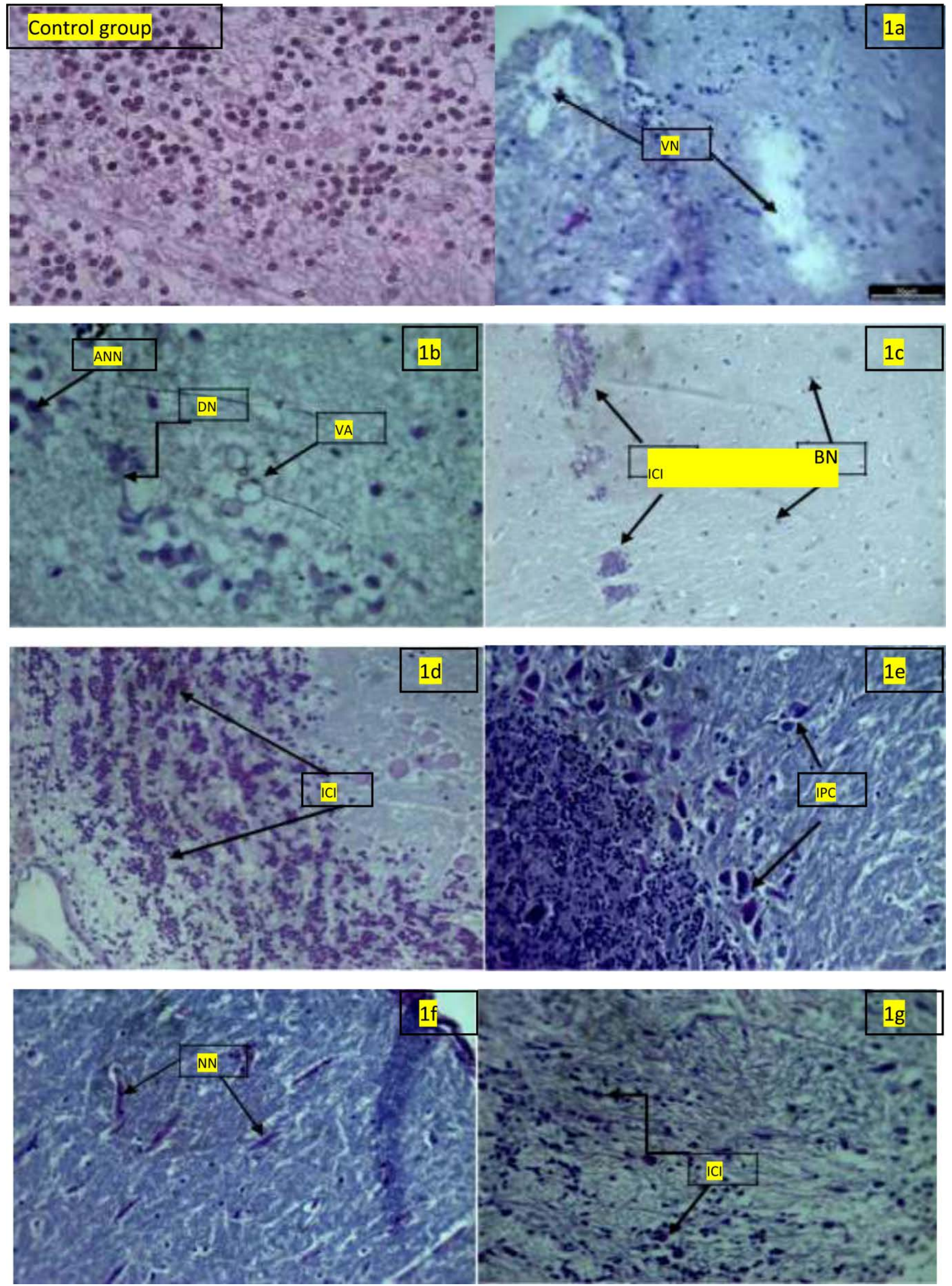

Figure 1. Control group. 1a; Vacuolization of Neuropil (VN), 1b; Degenerated Neurons (DN), Vacuolization (VA), Acute Necrosis of Neurons (ANN), 1c; Inflammatory Cell Infiltration (ICI), Binucleate Formation (BN), 1d; Inflammatory Cell Infiltration (ICI), 1e; Irregular Pyramidal Cells (IPC), 1f; Neural Necrosis (NN), 1g; Inflammatory Cell Infiltration (ICI). 
Table 1. Summarized comparison of histopathological effects in the brain tissue of $C$. idella exposed to atrazine.

\begin{tabular}{|c|c|c|c|c|c|c|c|c|}
\hline $\begin{array}{c}\text { Concentration } \\
\mu \mathrm{l} / \mathrm{L}\end{array}$ & $\begin{array}{l}\text { Degenerate } \\
\text { d Neurons } \\
\text { (DN) }\end{array}$ & $\begin{array}{l}\text { Vacuolization } \\
\text { (VA) }\end{array}$ & $\begin{array}{l}\text { Inflammatory } \\
\text { Cell Infiltration } \\
\text { (ICI) }\end{array}$ & $\begin{array}{l}\text { Acute Necrosis } \\
\text { of Neurons } \\
\text { (ANN) }\end{array}$ & $\begin{array}{c}\text { Vacuolization } \\
\text { of Neuropil } \\
\text { (VN) }\end{array}$ & $\begin{array}{c}\text { Irregular } \\
\text { Pyramidal Cells } \\
\text { (IPC) }\end{array}$ & $\begin{array}{l}\text { Neurol } \\
\text { Necrosis } \\
(\mathrm{NN})\end{array}$ & $\begin{array}{c}\text { Binucleate } \\
\text { Formation } \\
\text { (BN) }\end{array}$ \\
\hline Control (0) & - & - & - & - & - & - & - & - \\
\hline 0.025 & +++ & ++ & +++ & + & + & + & ++ & + \\
\hline 0.03 & +++ & +++ & +++ & ++ & ++ & ++ & +++ & ++ \\
\hline
\end{tabular}
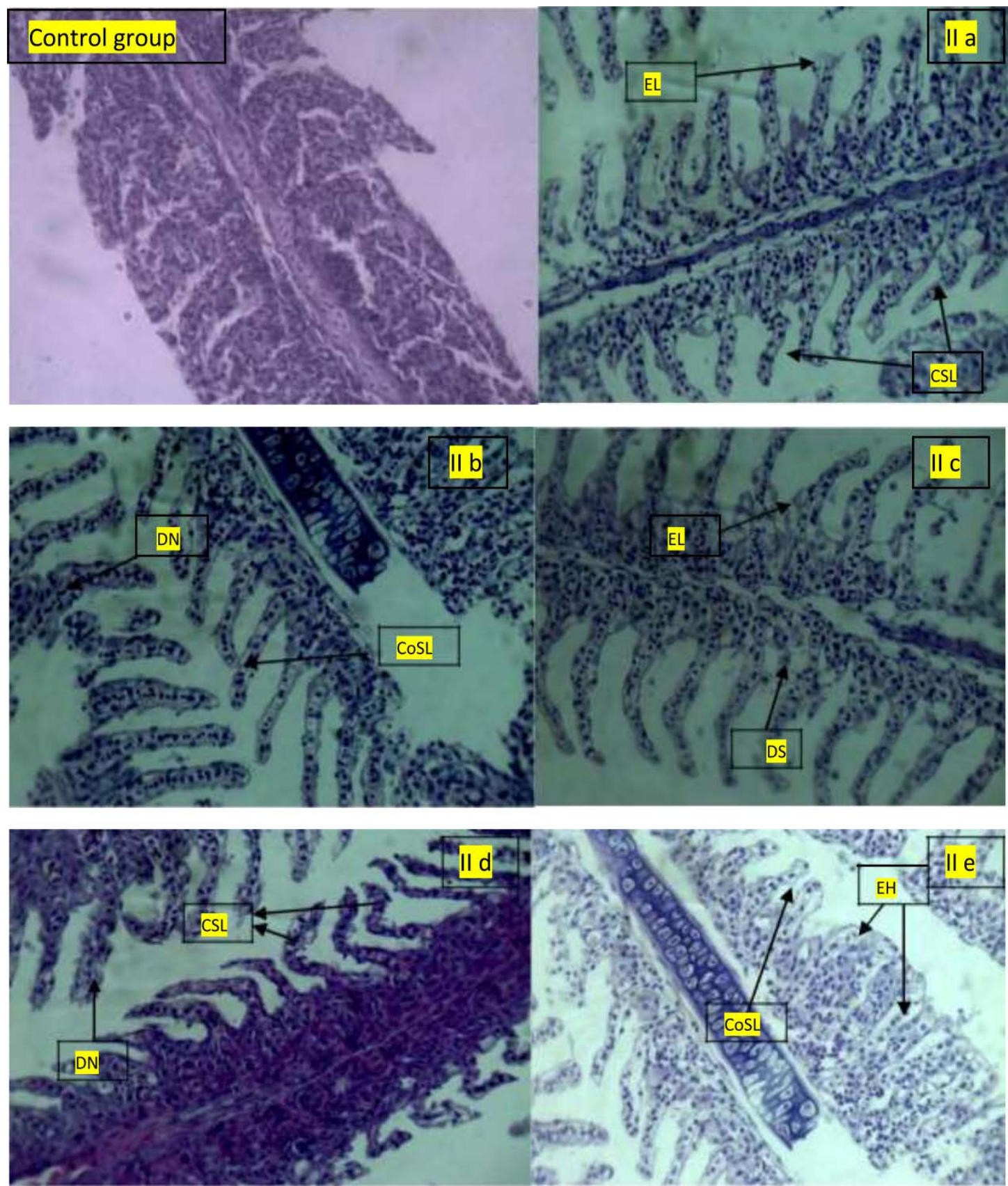

Figure 2. Control group. IIa; Epithelial Lifting (EL), Curling of Secondary Lamellae (CSL), IIb; Desquamation and Necrosis (DN), Collapsed Secondary Lamellae (CoSL), IIc; Epithelial Lifting (EL), Desquamation and Necrosis (DN), IId; Curling of Secondary Lamellae (CSL), Desquamation and Necrosis (DN), IIe; Epithelial Hyperplasia (EH), Collapsed Secondary Lamellae (CoSL). 
$\mu \mathrm{l} / \mathrm{L}$ exposure to atrazine concentration showed several changes including epithelial hyperplasia, epithelial lifting, collapsed secondary lamellae, curling of secondary lamellae, lamellar fusion, smaller aneurism and larger aneurism hyperplasia as shown in Figure 2, with the most dominant alteration at all concentrations of atrazine were desquamation and necrosis as shown in Figure 2(b) and Figure 2(d). Severity of anomalies of gills tissues in comparison with control group against atrazine doses is shown in Table 2 .

Similarly no histopathological changes were seen in the liver tissue of the control fish. The structural details of the liver tissue of control $C$. idella are shown in Figure 3. Photomicrograph of the liver tissues of fish exposed to atrazine groupings of 0.025 and $0.03 \mu \mathrm{l} / \mathrm{L}$ represents cloudy swelling of hepatocytes followed by vacuolar degeneration and dilation of sinusoids were observed. Karyolysis and karyohexis were the dominant anomalies throughout the study against each dose as shown in Figure 3(b) and Figure 3(g). The histological changes noticed in the atrazine exposed liver tissue and control group are shown in Table 3 .

\section{Discussion}

Different anthropogenic squanders are discharged in water bodies unfavorably influencing aquatic life, particularly fish. Histopathology status is valuable to decide the impacts of anthropogenic poisons on the organisms as histopathology is the microscopic investigation of diseased or harmed tissue and it is a significant instrument of anatomical pathology and histopathological biomarkers mirror the general wellbeing status of populace in a biological system (Khoshnood et al., 2010).

In the current investigation, it is plainly shown that atrazine has induced pronounced pathological neurotic changes in the brain tissue of the fish C. idel1a. The histopathological reactions of the fish uncover the level of harm brought

Table 2. Summarized comparison of histopathological effects in the gills tissue of $C$. idella exposed to atrazine.

\begin{tabular}{ccccccccc}
\hline $\begin{array}{c}\text { Concentration } \\
\mu \mathrm{l} / \mathrm{L}\end{array}$ & $\begin{array}{c}\text { Epithelial } \\
\text { Hyperplasia } \\
(\mathrm{EH})\end{array}$ & $\begin{array}{c}\text { Desquamation } \\
\text { and Necrosis } \\
(\mathrm{DN})\end{array}$ & $\begin{array}{c}\text { Epithelial } \\
\text { Lifting } \\
(\mathrm{EL})\end{array}$ & $\begin{array}{c}\text { Collapsed } \\
\text { Secondary } \\
\text { Lamellae (CoSL) }\end{array}$ & $\begin{array}{c}\text { Curling of } \\
\text { Secondary } \\
\text { Lamellae (CSL) }\end{array}$ & $\begin{array}{c}\text { Lamellar } \\
\text { Fusion (LF) }\end{array}$ & $\begin{array}{c}\text { Smaller } \\
\text { Aneurism } \\
\text { (SA) }\end{array}$ & $\begin{array}{c}\text { Larger } \\
\text { Aneurism } \\
\text { (LA) }\end{array}$ \\
\hline $\begin{array}{c}\text { Control }(0) \\
0.025\end{array}$ & - & - & - & - & - & - & - & - \\
0.03 & ++ & +++ & ++ & + & ++ & + & ++ & ++ \\
\hline
\end{tabular}

Table 3. Summarized comparison of histopathological effects in the liver tissue of $C$. idella exposed to atrazinet.

\begin{tabular}{ccccccc}
\hline $\begin{array}{c}\text { Concentration } \\
\mu \mathrm{l} / \mathrm{L}\end{array}$ & $\begin{array}{c}\text { Focal Necrosis } \\
(\mathrm{FN})\end{array}$ & $\begin{array}{c}\text { Cloudy Swelling of } \\
\text { Hepatocytes (CSH) }\end{array}$ & $\begin{array}{c}\text { Vacuolar } \\
\text { Degeneration (VD) }\end{array}$ & $\begin{array}{c}\text { Karyolysis } \\
(\mathrm{KL})\end{array}$ & $\begin{array}{c}\text { Karyohexis } \\
\text { (KH) }\end{array}$ & $\begin{array}{c}\text { Dilation of } \\
\text { Sinusoids (DS) }\end{array}$ \\
\hline Control $(0)$ & - & - & - & - & - & - \\
0.025 & ++ & ++ & + & +++ & +++ & ++ \\
0.03 & +++ & +++ & ++ & +++ & +++ & +++ \\
\hline
\end{tabular}



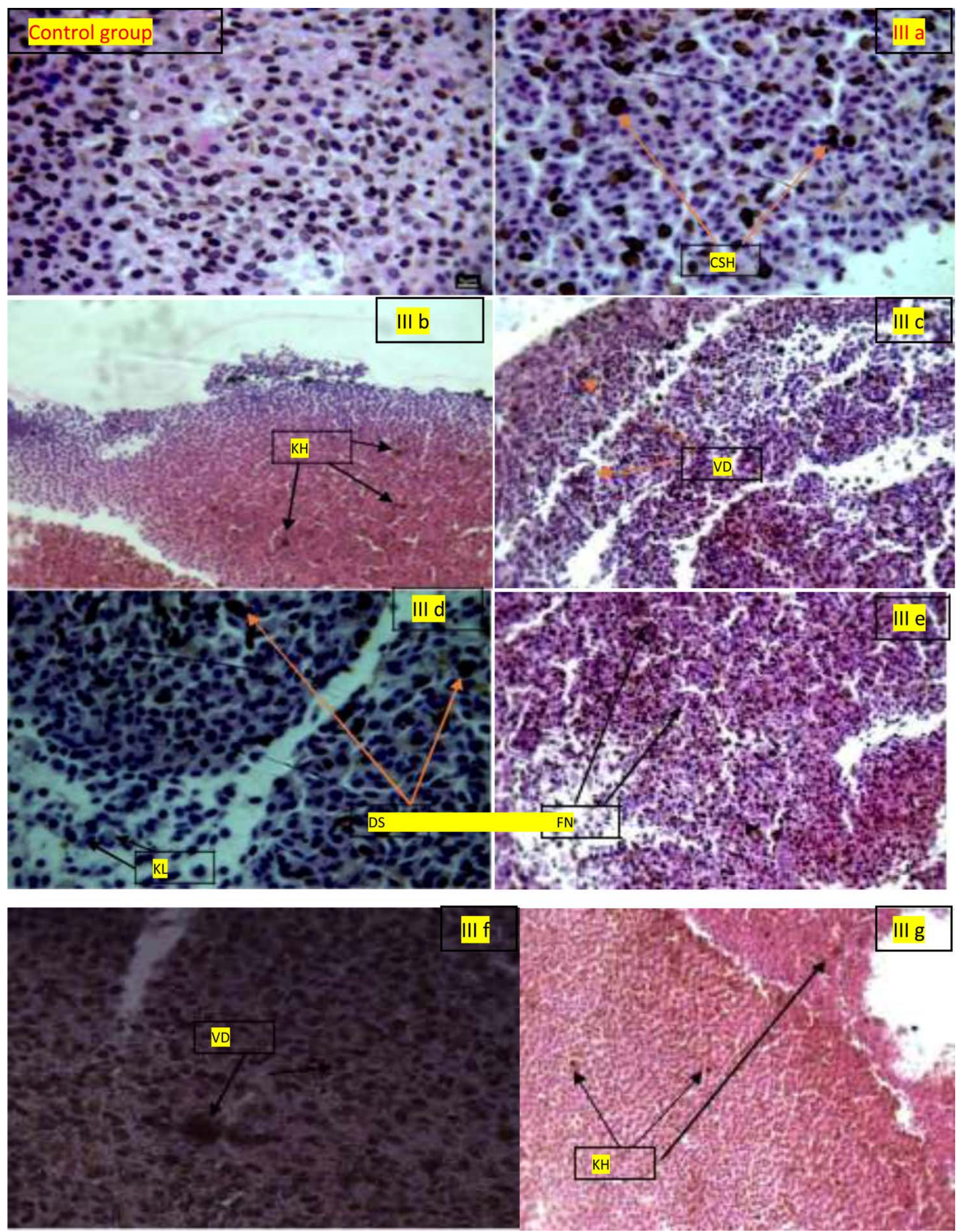

Figure 3. Control group. IIIa; Cloudy Swelling of Hepatocytes (CSH), IIIb; Karyohexis (KH), IIIc; Vacuolar Degeneration (VD), IIId; Dilation of Sinusoids (DS), Karyolysis (KL), IIIe; Focal Necrosis (FN), IIIf; Vacuolar Degeneration (VD). IIIg; Karyohexis (KH). 
about by this herbicide to the cerebrum of the fish. The degree of harm caused and the degenerative changes that were happened in the brain of the fish because of atrazine poisonousness were dynamic over the time of introduction, propose that the histopathological changes depend on the concentrations of chemicals as well as on the length of the fish presentation period to these synthetic compounds. Several authors have documented diverse histopathological changes in the brain tissue of fishes in the wake of presenting to various concoction substances (Basanta \& Subhas, 2000; Ayoola \& Ajani, 2008). Basanta and Subhas (2000) observed mild vacuolar changes in the cerebrum with void spaces after $0.35 \mathrm{ppm}$ hexachloro cyclohexane exposure, whereas at $1.73 \mathrm{ppm}$ they have observed severe necrosis of neuronal cells of cerebrum and loss of nissl substance in the brain of the Indian major carp (Labeo rohita), exposed to hexachlorocyclohexane. Ayoola and Ajani (2008) announced mononuclear invasion, neuronal degeneration and extreme spongiosis in the cerebrum of the fish Clarias gariepinus subsequent to presenting to deadly groupings of cypermethrin. There was a serious blockage, mononuclear penetration, drain and summed up spongiosis in the cerebrum of the fish Oreochromis niloticus presented to deadly convergences of glyphosate (Ayoola, 2008).

Different regions in fish brain are concerned about various kind important roles. The hindrance of tissue of a region in the brain by these obsessive changes may lead into the decrease of the specific function in fishes. This alters the physiological and behavioral elements of the fish. This is confirming in the behavior of the fish as respiratory trouble, loss of harmony and unpredictable swimming as announced in the current investigation. Bradbury et al. (1987) noticed tremors and seizures in rainbow trout because of the harmful impact on mind on introduction to fenvalerate. Sajitha (2006) observed vascular enlargement in fish mind on introduction to 2,4-D and endosulfan separately. Pugazhvendan et al. (2009) reported scatterly masterminded cells, extreme rot and loss of separation in the synapses in Ophiocephalus punctatus presented to malathion pesticide is in the line with the current findings.

The pathologic test of gill tissues in fish exposed to environmental toxins has been utilized as a valuable biomarker (Simonato et al., 2008). Gills are extremely important in respiration, osmoregulation, acid-base equalization, and discharge of nitrogenous squanders (Simonato et al., 2008), and they represent the best surface area of the animal in contact with external environment. In the current findings, gills tissue of fish in the untreated group indicated normal structure, while atrazine uncovered fish groups demonstrated degenerative changes in their gills. Seriousness of harm expanded with increase grouping of atrazine. Gills anomalies of fish that is exposed to atrazine included epithelial lifting, collapsed secondary lamellae, curling of secondary lamellae, lamellar fusion, smaller aneurism and larger aneurism. Tietge et al. (1988) revealed that hyperplasia (increment in cells of the optional lamellae) and epithelial lifting (height of the outer layer of the lamellar epithelium) are defensive components of fish towards 
contaminations. In the current examination, epithelial lifting and hyperplasia were seen in gills exposed to an inclination of atrazine concentration. The main change in the gills under intense introduction to the poisonous included lifting of the lamellar epithelium. Comparable epithelium lifting were seen by Muller and Lloyd (1994) in fish gills presented to oils, alkali, cleansers, acids, and metals like mercury, and phenols. Lamellar fusion and curling of secondary lamellae were seen in fish gills exposed to atrazine. Comparative changes in fish gills were recorded as a reaction to copper pollutants by Arellano et al. (1999) effluents from a dying paper plant (Pacheco \& Santos, 2002) and sewage from an secondary treatment plant (Coutinho \& Gokhale, 2000). Figueiredo-Fernandes et al. (2007) clarified that fusion of some secondary lamellae causes decrease of the branchial superficial region that is in contact with the outer environment.

Many investigators have reported the histopathological changes in gills tissue of different fish species exposed to pesticides. Mucus extrusion, lamellar swelling, fused and reduced microridges, were observed in bluegill sunfish, Lepomis macrochirus to different sublethal concentrations of diazinon (Dutta et al., 1997). Histopathological effects of sublethal concentrations of monocrotophos on the gills of Anabas testudineus were reported by Santhakumar et al. (2001). Degenerative changes in gill, such as intraepithelial edema in the secondary lamellae, thick coating of mucus covering the entire gill filaments and lamellae, erosion of secondary lamellae, thickening of lamellae, inflammation of epithelial cells, desquamation, breakages in primary lamellae, degeneration of secondary lamellae, necrosis, rupture of epithelium, smaller aneurism and larger aneurism were noticed during exposure of sublethal concentrations of monocrotophos by Rao et al. (2005). Comparative histological changes have been accounted for in the gills of fish presented to sodium dodecyl sulfate (Rosety-Rodrdguez et al., 2002), and diazinon at 0 (control), 1, 2, and $3 \mathrm{mg} \cdot \mathrm{L}^{-1}$ (Khosravi et al., 2014) which are in agreement with the current observations. Further a potential justification for our findings may be because of resistance components of Ctenopharngodon idella bringing about the expanded separation between the aquatic environment and the blood and act as an obstruction to the contaminations' passageway, These adjustments in the gill structure lead to disability of oxygen take-up, and fish need to build their respiration rate by compensation (Fernandes \& Mazon, 2003).

Fish liver tissue is the principle organ for detoxification of xenobiotics, including atrazine. Along these lines, the basic changes in liver tissue of aquatic fauna, for example, reflective of aquatic pollution and their natural surroundings (Moon et al. 2012). During digestion, liver can separate these hurtful substances, yet past a specific cutoff, these harmful substances upset the directing system of the liver and cause morphological modification (Brusle et al., 1996).

Liver histology is highly sensitive and is a precise method to survey the impact of any contamination on fish. Exposure to the sublethal concentrations of atrazine changed the normal architecture of liver, increment lipid like vacuolization and irritation in sinusoids. Comparable changes were recorded in the liver of 
Catla catla treated against 1 - 4 ppm BPA (Faheem et al., 2016). Dilated sinusoids and change in liver typical structure might be because of the loss of structural proteins after the poisonous exposure. One of the nonspecific responses of fish in harmful conditions is hepatocyte vacuolation (Roberts, 1978) and this vacuolization is typical of lipid accumulation in liver or the vacuolization of hepatocytes might indicate an imbalance between the rate of synthesis of substances in the parenchyma cells and the rate of their release into the circulation (Gingerich, 1982). Comparative changes in liver were accounted by Peixoto et al. (2013) in Barbusbocagei got from Vizela Waterway, Portugal. Ameur et al. (2012) discovered comparable histopathologic changes in liver of Mugil cephalus and Dicentrarchus labrax from Bizerte Tidal pond, Tunisia. El-Jawaher (2012) documented comparable changes in hepatocytes of Oreochromus spilurus presented to nonylphenol (endocrine upsetting synthetic). Abdel-Aziz et al. (2006) additionally reported unusual liver tissue architecture of Siganus rivulates presented to overwhelming metals which is in accordance with the current discoveries.

\section{Conclusion}

Atrazine herbicide shows severe toxicity to fish tissues that have been reported in the current study as all the histopathological observation indicated that exposure to sublethal concentrations of atrazine caused destructive effect in the brain, gills and liver tissues of $C$. idella. All these tissues histopathological alterations, such as those observed in this study and findings from previous studies, could result in severe physiological problems, ultimately leading to the death of fish. As a conclusion, the findings of the present histological investigations demonstrated a direct correlation between pesticide exposure and histopathological disorders observed in several tissues. Frequency and intensity of tissue lesions depend on the concentration of pesticides and the length of the fish exposure period to pesticides. The results of this study clearly indicated that atrazine at acute concentration is toxic to grass carp. Hence, no restrictions on the indiscriminate use of pesticide can play a role in decreasing the wild population of fish in natural water bodies.

\section{Acknowledgements}

We are thankful to Department of Zoology, University of Swabi for their support in providing lab facilities to us in our research work.

\section{Conflicts of Interest}

The authors declare no conflicts of interest regarding the publication of this paper.

\section{References}

Abdel-Aziz, S. H., El-Ghazaly, N., \& Dohaishel, E. G. B. (2006). Effect of Pollutants in Coastal Water of Jeddah on the Histological Structure of Liver of the Fish Siganus ri- 
vulatus, Saudi Arabia. Egyptian Journal of Aquatic Research, 32, 316-333.

Adedeji, O. B., Adeyemo, O. K., \& Agbede, S. A. (2009). Effects of Diazinon on Blood Parameters in the Catfish (Clarias gariepinus). African Journal of Biotechnology, 8, 3940-3946.

Ameur, W. B., Lapuente, J., Megdiche, Y., Barhoumia, B., Trabelsi, S., Camps, L., Serret, J., Ramos-Lopez, D., Gonzalez, L. J., Driss, M. R., \& Borras, M. (2012). Oxidative Stress, Genotoxicity and Histopathology Biomarker Responses in Mullet and Sea Bass Liver from Bizerte Lagoon (Tunisia). Marine Pollution Bulletin, 64, 241-251. https://doi.org/10.1016/j.marpolbul.2011.11.026

Arellano, J. M., Storch, V., \& Sarasquete, C. (1999). Histological Changes and Copper Accumulation in Liver and Gills of the Senegales Sole, Solea senegalensis. Ecotoxicology and Environmental Safety, 44, 62-72. https://doi.org/10.1006/eesa.1999.1801

Asita, A. O., \& Makhalemele, R. (2008). Genotoxicity of Chlorpyrifos, Alpha-Thrin, Efektovirikop and Springbok to Onion Root Tip Cells. African Journal of Biotechnology, $7,4244-4250$.

Ayoola, S. O. (2008). Toxicity of Glyphosate Herbicide on Nile Tilapia Oreochromis niloticus Juvenile. African Journal of Agricultural Research, 3, 825-834.

Ayoola, S. O., \& Ajani, E. K. (2008). Histopathological Effects of Cypermethrin on Juvenile African Catfish (Clarias gariepinus). World Journal of Biological Research, 1, 1-14.

Basanta, K. D., \& Subhas, C. M. (2000). A Histopathological Study of Carp Labeo rohita Exposed to Hexachlorocyclohexane. Veterinarski Arhiv, 70, 169-180.

Bell, R. R., Nonavinakere, V. K., \& Soliman, M. R. (2000). Intratracheal Exposure of the Guinea Pig Lung to Cadmium and/or Selenium: A Histological Evaluation. Toxicol Letters, 114, 101-109. https://doi.org/10.1016/S0378-4274(99)00286-6

Bradbury, S. P., McKim, J. M., \& Coats, J. R. (1987). Physiological Response of Rainbow Trout (Salmo gairdneri) to Acute Fenvalerate Intoxication. Pesticide Biochemistry and Physiology, 27, 275-288. https://doi.org/10.1016/0048-3575(87)90057-5

Brusle, J., Gonzalez, I., \& Anadon, G. (1996). The Structure and Function of Fish Liver, in Fish Morphology. New York: Science Publishers.

Cerejeira, M. J., Viana, P., Batista, S., Pereira, T., Silva, E., Valerio, M. J., Silva, A., Ferreira, M., \& Silva-Fernandes, A. M. (2003). Pesticides in Portuguese Surface and Ground Waters. Water Research, 37, 1055-1063. https://doi.org/10.1016/S0043-1354(01)00462-6

Coutinho, C., \& Gokhale, K. S. (2000). Selected Oxidative Enzymes and Histopathological Changes in the Gills of Cyprinus carpio and Oreochromis mossambicus Cultures in Secondary Sewage Effluent. Water Research, 34, 2997-3004.

https://doi.org/10.1016/S0043-1354(00)00050-6

Cui, H., Hwang, H. M., Zeng, K., Glover, H., Yu, H., \& Liu, Y. (2002). Riboflavin Photo Sensitized Degradation of Atrazine in a Freshwater Environment. Chemosphere, 47, 991-999. https://doi.org/10.1016/S0045-6535(02)00006-1

Du Preez, H. H., \& van Vuren, J. H. J. (1992). Bioconcentration of Atrazine in the Banded Tilapia, Tilapia sparrmanii. Comparative Biochemistry and Physiology Part C: Comparative Pharmacology, 101, 651-655. https://doi.org/10.1016/0742-8413(92)90100-L

Dutta, H. M., Munshi, J. S. D., Roy, P. K., Singh, N. K., Motz, L., \& Adhikari, S. (1997). Effects of Diazinon on Bluegill Sunfish, Lepomis macrochirus, Gills: Scanning Electron Microscope Observations. Experimental Biology Online, 2, 1-11. https://doi.org/10.1007/s00898-997-0017-4

El-Jawaher, A. B. D. (2012). The Effects of 4-Nonylphenol Contamination on Liver of Ti- 
lapia Fish (Oreochromus spilurus) in Jeddah. Biological Research, 45, 15-20. https://doi.org/10.4067/S0716-97602012000100002

Faheem, M., Jahan, N., \& Lone, K. P. (2016). Histopathological Effects of Bisphenol-A on Liver, Kidneys and Gills of Indian Major Carp, Catla catla (Hamilton, 1822). Journal of Animal and Plant Sciences, 26, 514-522.

Fernandes, M. N., \& Mazon, A. F. (2003). Environmental Pollution and Fish Gill Morphology. In A. L. Val, \& B. G. Kapoor (Eds.), Fish Adaptation (pp. 2003-2031). New York: Science Publishers.

Figueiredo-Fernandes, A., Ferreira-Cardoso, J. V., Garcia-Santos, S., Monteiro, S. M., Carrola, J., Matos, P., \& Fontainhas, F. A. (2007). Histopathological Changes in Liver and Gill Epithelium of Nile Tilapia, Oreochromis niloticus, Exposed to Waterborne Copper. Pesquisa Veterinária Brasileira, 27, 103-109. https://doi.org/10.1590/S0100-736X2007000300004

Gingerich, W. H. (1982). Hepatic Toxicology in Fish. In L. J. Weber (Ed.), Aquatic Toxicology (pp. 55-105). New York: Raven Press.

Grobler, E., Van Vuren, J. J. J., \& Du Preez, H. H. (1989). Routine Oxygen Consumption of Tilapia sparrmanii (Cichlidae) Following Acute Exposure to Atrazine. Comparative Biochemistry and Physiology Part C: Comparative Pharmacology, 93, 37-42. https://doi.org/10.1016/0742-8413(89)90007-8

Hussein, S. Y., El-Nasser, M. A., \& Ahmed, S. M. (1996). Comparative Studies on the Effects of Herbicide Atrazine on Freshwater Fish Oreochromis niloticus and Chrysichthyes auratusat Assiut, Egypt. Bulletin of Environmental Contamination and Toxicology, 57, 503-510. https://doi.org/10.1007/s001289900218

Jabeen, G., \& Javed, M. (2012). Evaluation of Arsenic Toxicity to Biota in River Ravi (Pakistan) Aquatic Ecosystem. International Journal of Agriculture and Biology, 13, 929-934.

Javed, M. (2012). Effects of Metals Mixture on the Growth and Their Bioaccumulation in Juvenile Major Carps. International Journal of Agriculture and Biology, 14, 477-480.

Khan, B., Khan, H., Muhammad, S., \& Khan, T. (2012). Heavy Metals Concentration Trends in Three Fish Species from Shah Alam River Pakhtunkhwa Province, Pakistan. Journal of Natural \& Environmental Sciences, 3, 1-8.

Khoshnood, Z., Khodabandeh, S., Mosafer, S., \& Khoshnood, R. (2010). Effects of Cortisol on Gill Chloride Cells in Persian Sturgeon, Acipenser persicus Fry. Yakhteh Medical Journal, 11, 424-431.

Khosravi, K. K., Amiri, B. M., Massarsky, A., \& Yelghi, S. (2014). Impact of a Short-Term Diazinon Exposure on the Osmoregulation Potentiality of Caspian Roach (Rutilu srutilus) Fingerlings. Chemosphere, 108, 396-404.

Könen, S., \& Çavaş, T. (2008). Genotoxicity Testing of the Herbicide Trifluralin and Its Commercial Formulation Treflan Using the Piscine Micronucleus Test. Environmental and Molecular Mutagenesis, 49, 434-438. https://doi.org/10.1002/em.20401

Matsumoto, S. T., Mantovani, M. S., Malaguttii, M. I. A., Dias, A. U., Fonseca, I. C., \& Marin-Morales, M. A. (2006). Genotoxicity and Mutagenicity of Water Contaminated with Tannery Effluents, as Evaluated by the Micronucleus Test and Comet Assay Using the Fish Oreochromis niloticus and Chromosome Aberrations in Onion Root-Tips. Genetics and Molecular Biology, 29, 148-158.

https://doi.org/10.1590/S1415-47572006000100028

Moon, M. K., Kim, M. J., Jung, I. K., Koo, Y. D., Ann, H. Y., Lee, K. J., Kim, S. H., Yoon, Y. C., Cho, B. J., Park, K. S., Jang, H. C., \& Park, Y. J. (2012). Bisphenol A Impairs Mitochondrial Function in the Liver at Doses below the No Observed Adverse Effect Lev- 
el. Journal of Korean Medical Science, 27, 644-652.

https://doi.org/10.3346/jkms.2012.27.6.644

Muller, R., \& Lloyd, R. (1994). Sublethal and Chronic Effects of Pollutants on Freshwater Fish (371 p). Oxford, UK: FAO and Fishing News Books.

Nagarani, N., Devi, V. J., \& Kumaraguru, A. K. (2012). Identification of DNA Damage in Marine Fish Therapon jarbua by Comet Assay Technique. Journal of Environmental Sciences, 33, 699-703.

Naqvi, G. Z., Shoaib, N., \& Ali, A. M. (2016). Genotoxic Potential of Pesticides in the Peripheral Erythrocytes of Fish (Oreochromis mossambicus). Pakistan Journal of Zoology, 48, 1643-1648.

Nikalje, S. B., Muley, D. V., \& Angadi, S. M. (2012). Histopathological Changes in Liver of Freshwater Major Carp, Labeo rohita after Acute and Chronic Exposure to Textile Mill Effluent. The Bioscan, 7, 215-220.

Pacheco, M., \& Santos, M. A. (2002). Biotransformation, Genotoxic, and Histopathological Effects of Environmental Contaminants in European Eel (Anguilla anguilla). Ecotoxicology and Environmental Safety, 53, 331-347. https://doi.org/10.1016/S0147-6513(02)00017-9

Pandey, R. K., Singh, R. N., \& Das, V. K. (2008). Effect of Temperature on Mortality and Behavioural Responses in freshwater Catfish, Heteropneustes fossilis (Bloch) Exposed to Dimethoate. Global Journal of Environmental Research, 2, 126-132.

Peixoto, F. P., Carrola, J., Coimbra, A. M., Fernandes, C., Teixeira, P., Coelho, L., Conceicao, I., Oliveira, M. M., \& Fontaínhas-Fernandes, A. (2013). Oxidative Stress Responses and Histological Hepatic Alterations in Barbel, Barbus Bocagei, from Vizela River, Portugal. Revista Internacional de Contaminación Ambiental, 29, 29-38.

Phyua, Y. L., Warne, M. S. J., \& Lim, R. P. (2006). Toxicity and Bioavailability of Atrazine and Molinate to the Freshwater Fish (Melanotenia fluviatilis) under Laboratory and Simulated Field Conditions. Science of the Total Environment, 356, 86-99. https://doi.org/10.1016/j.scitotenv.2005.04.003

Prasad, T. A. V., Srinivas, T., Rafi, G. M., \& Reddy, D. C. (1991). In Vivo Effect of Atrazine on Haematology and $\mathrm{O}_{2}$ Consumption in Fish Tilapia mossambica. Biochemistry International, 23, 157-161.

Prasad, T. A. V., Srinivas, T., Reddy, J. S., \& Reddy, D. C. (1995). Atrazine Toxicity on Transport Properties of Hemocyanin in the Crab Oziotelphusa senex senex. Ecotoxicology and Environmental Safety, 30, 124-126. https://doi.org/10.1006/eesa.1995.1015

Pugazhvendan, S. R., Narendiran, N. J., Kumaran, R. G., Kumaran, S., \& Alagappan, K. M. (2009). Effect of Malathion Toxicity in the Freshwater Fish Ophiocephalus punctatus-A Histological and Histochemical Study. World Journal of Fish and Marine Sciences, 1, 218-224.

Rao, J. V., Begum, G., Sridhar, V., \& Reddy, N. C. (2005). Sublethal Effects of Monocrotophos on Locomotor Behavior and Gill Architecture of the Mosquito Fish, Gambusia affinis. Journal of Environmental Science and Health, Part B, 40, 813-825. https://doi.org/10.1080/03601230500227509

Rauf, A., Javed, M., \& Ubaidulalh, M. (2009). Heavy Metal Levels in Three Major Carps (Catla catla, Labeo rohita and Cirrhina mrigala) from the River Ravi, Pakistan. Pakistan Veterinary Journal, 29, 24-26.

Roberts, R. J. (1978). Fish Pathology (466 p). London: Bailliere Tindall.

Rosety-Rodrdguez, M., Ordoez, F. J., Rosety, M., Roset, J. M., Ribelles, A., \& Carrasco, C. (2002). Morpho-Histochemical Changes in the Gills of Turbot, Scophthalmus maximus Induced by Sodium Dodecyl Sulfate. Ecotoxicology and Environmental Safety, 51, 
223-228. https://doi.org/10.1006/eesa.2001.2148

Roy, S., Chattoraj, A., \& Bhattacharya, S. (2006). Arsenic-Induced Changes in Optictectal Histoarchitecture Acetylcholinesterase-Acetylcholineprofile in Channa punctatus. Amelioration by Selenium. Comparative Biochemistry and Physiology Part C: Toxicology \& Pharmacology, 144, 16-24. https://doi.org/10.1016/j.cbpc.2006.04.018

Sajitha, B. (2006). Toxicological Evaluation of Endosulfan in Anabas testudineus. M. Phil Thesis, Pondicherry, India: University of Pondicherry.

Santhakumar, M., Balaj, M., \& Ramudu, K. (2001). Gill Lesions in the Perch, Anabas testudineus, Exposed to Monocrotophos. Journal of Environmental Biology, 22, 87-90.

Simonato, J. D., Guedes, C. L. B., \& Martinez, C. B. R. (2008). Biochemical, Physiological, and Histological Changes in the Neotropical Fish Prochilodus lineatus Exposed to Diesel Oil. Ecotoxicology and Environmental Safety, 69, 112-120. https://doi.org/10.1016/j.ecoenv.2007.01.012

Sinaie, M., Bastami, K. D., Ghorbanpour, M., Najafzadeh, H., Shekari, M., \& Haghparast, S. (2010). Metallothionein Biosynthesis as a Detoxification Mechanismin Mercury Exposure in Fish, Spotted Scat (Scatophagus argus). Fish Physiology and Biochemistry, 36, 1235-1242. https://doi.org/10.1007/s10695-010-9403-x

Srinivas, T., Prasad, T. A. V., Raffi, G. M., \& Reddy, D. C. (1991). Effect of Atrazine on Some Aspects of Lipid Metabolism in Fresh Water Fish. Biochemistry International, 23, 603-609.

Theodorakis, C. W., Bickham, J. W., Elbl, T., Shugart, L. R., \& Chesser, R. K. (1998). Genetics of Radionuclide Contaminated Mosquitofish Populations and Homology between Gambusia affinis and G. holbrooki. Environmental Toxicology and Chemistry, 17, 1992-1998. https://doi.org/10.1002/etc.5620171015

Tietge, J. E., Johnson, R. D., \& Bergman, H. L. (1988). Morphometric Changes in Gill Secondary Lamellae of Brook Trout (Salvelinus fontinalis) after Long Term Exposure to Acid and Aluminum. Canadian Journal of Fisheries and Aquatic Sciences, 45, 1643-1648.

Tolosa, I., de Mora, S. J., Fowler, S. W., Villeneuve, J.-P., Bartocci, J., \& Cattini, C. (2005). Aliphatic and Aromatic Hydrocarbons in Marine Biota and Coastal Sediments from the Gulf and the Gulf of Oman. Marine Pollution Bulletin, 50, 1619-1633.

https://doi.org/10.1016/j.marpolbul.2005.06.029

US Environmental Protection Agency (USEPA) (1988). Method 525. Determination of Organic Compounds in Drinking Water by Liquid-Solid Extraction and Capillary Column Gas Chromatography/Mass Spectrometry. In Methods for the Determination of Organic Compounds in Drinking Water (pp. 325-356). EPA Report No. EPA-600/ 4-88/039; US NTIS PB89-220461, Cincinnati, OH: Environmental Monitoring Systems Laboratory.

Velmurugan, B., Mathews, T., \& Cengiz, E. I. (2009). Histopathological Effects of Cypermethrin on Gill, Liver and Kidney of Fresh Water Fish Clarias gariepinus (Burchell, 1822), and Recovery after Exposure. Environmental Technology, 30, 1453-1460. https://doi.org/10.1080/09593330903207194

Vinodhini, R., \& Narayana, M. (2009). Heavy Metal Induced Histopathological Alterations in Selected Organs of the Cyprinus carpio L. (Common Carp). International Journal of Environmental Research, 3, 95-100.

Waring, C. P., \& Moore, A. (2004). The Effect of Atrazine on Atlantic Salmon (Salmo salar) Smolts in Fresh Water and after Sea Water Transfer. Aquatic Toxicology, 66, 94-104. https://doi.org/10.1016/j.aquatox.2003.09.001

WHO (1996). Guidelines for Drinking-Water Quality, 2nd ed. Vol. 2. Health Criteria and 
Other Supporting Information. Geneva: World Health Organization.

Zuloaga, O., Prieto, A., Usobiaga, A., Sarkar, S. K., Chatterjee, M., Bhattacharya, B. D., Bhattacharya, A., Alam, A., \& Satpathy, K. K. (2009). Polycyclic Aromatic Hydrocarbons in Intertidal Marine Bivalves of Sunderban Mangrove Wetland, India: An Approach to Bioindicator Species. Water, Air, \& Soil Pollution, 201, 305-318.

https://doi.org/10.1007/s11270-008-9946-y 